\title{
Analisis Pengaruh Komitmen Organisasi dan Pengalaman Kerja terhadap Kinerja Karyawan (Studi PD. BPR BKK DEMAK Kantor Pusat Operasional, Kantor Cabang Wonosalam dan Kantor Cabang Karang Tengah)
}

\author{
Durrotul Chikmiyyah
}

Departement of Management, Wahid Hasyim University Semarang Menoreh Tengah X / 22, Sampangan, Kota Semarang, Indonesia chikmiya33@gmail.com

\section{Umar Chadhiq}

Departement of Management, Wahid Hasyim University Semarang Menoreh Tengah X / 22, Sampangan, Kota Semarang, Indonesia umarchadhiq@gmail.com

\section{Nanang Yusroni*}

Departement of Management, Wahid Hasyim University Semarang Menoreh Tengah X / 22, Sampangan, Kota Semarang, Indonesia

\section{nanangyusroni@gmail.com}

Diterima: 09-02-2021

Disetujui: 16-06-2021

Dipublikasi: 30-06-2021

\begin{abstract}
ABSTRAK
Artikel ini menganalisis tentang pengaruh pengalaman kerja dan komitmen organisasi terhadap kinerja karyawan PD. BPR BKK Demak. Pada pengujian secara simultan (uji f) variabel pengalaman kerja dan komitmen organisasi terhadap kinerja karyawan PD. BPR BKK Demak menunjukkan $\mathrm{f}$ hitung 3,756 > f tabel sebesar 3,25 dengan taraf signifikansi $0,048<0,05$ artinya secara bersama-sama terdapat pengaruh variabel pengalaman kerja dan komitmen organisasi terhadap kinerja karyawan PD. BPR BKK Demak. Hasil pengujian koefisien determinasi $\left(\mathrm{R}^{\wedge} 2\right)$ diperoleh angka 0,140 atau $14 \%$ terhadap variabel pengalaman kerja dan komitmen organisasi menunjukkan pengaruh terhadap kinerja karyawan PD.
\end{abstract}

Kata Kunci:

Pengalaman Kerja; Komitmen Organisasi; Kinerja Karyawan; BPR BKK

\begin{abstract}
This article analyzes the effect of work experience and organizational commitment on the performance of PD employees. The data analysis method used is validity test, reliability test, classic assumption test. BPR BKK Demak. In simultaneous testing (test $f$ ) work experience variables and organizational commitment to the performance of PD employees. BPR BKK Demak shows $f$ count 3.756> f table of 3.25 with a significance level of $0.048<0.05$, meaning that together there is a variable influence of work experience and organizational commitment on the performance of PD employees. BPR BKK Demak. The results of testing the coefficient of determination (obtained the figure 0.140 or $14 \%$ on the variables of work experience and organizational commitment show an effect on the performance of $P D$ employees.
\end{abstract}

Keywords:

Work Experience; Organizational Commitment; Employee Performance; BPR BKK 


\section{PENDAHULUAN}

Peranan kinerja dari karyawan sangat penting dan menentukan agar tercapainya tujuan dari suatu organisasi, sehingga menjadi tempat bagi para karyawan untuk melaksanakan tugas dan fungsinya masing-masing sesuai dengan bidangnya, para pegawai juga dituntut agar mampu melaksanakan tugas dan pekerjaannya dengan cepat, tepat dan teliti, agar nantinya tujuan dari organisasi dapat tercapai sesuai dengan yang telah diharapkan secara efektif dan efisien tanpa mengurangi kualitas dan kuantitas dari pelayanan yang diberikan kepada masyarakat, pelayanan suatu organisasi dapat dikatakan baik karena sumber daya manusianya yang mempunyai kualitas, kuantitas dan mutu yang baik.

Kinerja karyawan merupakan salah satu faktor yang sangat dominan dalam meningkatkan kinerja perusahaan. Kinerja pegawai merupakan hasil kerja secara kualitas adan kuantitas yang dicapai oleh seseorang pegawai dalam melaksanakan tugasnya sesuai dengan tanggung jawab yang diberikan kepadanya. Kinerja karyawan merupakan prestasi kerja atau hasil kerja (output) baik kualitas maupun kuantitas yang dicapai sumber daya manusia persatuan periode waktu dalam melaksanakan tugas kerjanya sesuai dengan tanggung jawab yang diberikan kepadanya oleh instansi atau perusahaan tersebut. Seperti halnya pada tujuan dari PD BPR BKK sendiri yaitu, untuk membantu dan mendorong pertumbuhan perekonomian dan pembangunan daerah di segala bidang serta dalam rangka meningkatkan taraf hidup rakyat sebagai salah satu sumber pendapatan daerah, dan salah satu tujuan itu diantaranya adalah untuk memperoleh laba maksimum. Usaha untuk memaksimumkan laba tentu bukan sesuatu yang mudah, jika kinerja karyawan bagus dalam arti dapat menjual /memasarkan produknya, maka kinerja perusahaan juga akan bagus pula, begitupun sebaliknya. Demikian pula pada perusahaan perbankan kinerjanya dapat dilihat dari aspek pemasarannya. Aspek ini tentunya dapat dilihat dari laporan keuangan yang meliputi Capital, Assets Quality, Management, Erning, serta Liquidity. Pada PD. BPR BKK Kabupaten Demak saat ini kecenderungan sedang mengalami penurunan kinerja yang tercermin dari pencapaian pendapatan. Berikut ini merupakan data pencapaian di PD. BPR BKK Demak Kantor Pusat Operasional, Kantor Cabang Wonosalam dan Kantor Cabang Karang Tengah pada tahun 2015 s/d 2018.

Berdasarkan tabel 1 menunjukkan fluktuasi atau naik turunnya pencapaian jumlah pendapatan pada PD. BPR BKK Demak Kantor Pusat OPerasional, PD. BPR BKK Kantor Cabang Wonosalam, dan PD. BPR BKK Kantor Cabang Karang Tengah. Dilihat dari keseluruhan pencapaian pendapatan pada PD. BPR BKK Kantor Pusat OPerasional terlihat ada penurunan jumlah pendapatan dari tahun 2017 ke tahun 2018 yang tadinya 103,157,509,323 berkurang menjadi 100,597,527,587. Selanjutnya pada PD. BPR BKK Kantor Cabang Wonosalam juga terjadi fenomena yang sama yaitu adanya penurunan jumlah pendapatan dari tahun 2017 ke tahun 2018 yang tadinya 4,827,388,000 berkurang menjadi 3,114,691,000 Dan pada PD. BPR BKK Kantor Cabang Karang Tenngah juga mengalami penurunaan jumlah pendapatan di tahun 2017 ke tahun 2018 yang tadinya 3,808,519,416 kini anjlok berkurang menjadi 3,618,123,746. Adanya fenomena tersebut akan menimbulkan banyak pertanyaan 
karena terjadi naik turunnya jumlah pendapatan. Hal tersebut akan menjadi masalah pada kinerja pegawai.

Tabel 1.

Data pencapaian Pendapatan di PD. BPR BKK DEMAK Kantor Pusat Operasional, Kantor Cabang Wonosalam dan Kantor Cabang Karang Tengah

\begin{tabular}{clcc}
\hline No & \multicolumn{1}{c}{ Instansi } & Tahun & Jumlah Pencapaian Pendapatan \\
\hline 1 & PD. BPR BKK Demak Kantor & 2015 & $96,115,107,828$ \\
& Pusat Operasional & 2016 & $98,769,147,707$ \\
& & 2017 & $103,157,509,323$ \\
& & 2018 & $100,597,527,587$ \\
2 & PD. BPR BKK Kantor Cabang & 2015 & $1,528,719,000$ \\
& Wonosalam & 2016 & $1,825,291,000$ \\
& & 2017 & $4,827,388,000$ \\
& & 2018 & $3,114,691,000$ \\
& & 2015 & $2,996,395,503$ \\
& PD. BPR BKK Kantor Cabang & 2016 & $3,556,782,694$ \\
& Karang Tengah & 2017 & $3,808,519,416$ \\
& & 2018 & $3,618,123,746$ \\
\hline
\end{tabular}

Sumber: PD. BPR BKK Demak, Febuari 2019.

Untuk menanggulanginya ada beberapa faktor yang harus diperhatikan diantaranya yaitu pengalaman kerja dan komitmen organisasi. Pengalaman kerja itu sendiri merupakan ukuran lamanya waktu atau masa kerja, tingkat pengetahuan dan keterampilan yang dimiliki dan penguasaan terhadap pekerjaan dan pearlatan untuk menciptakan pekerjaan yang lebih baik. Sedangkan komitmen organisasi yaitu sikap yang merefleksikan loyalitas pegawai pada organisasi dan proses berkelanjutan dimana pegawai mengekpresikan perhatiannya serta penerapannya dalam melaksanakan tugas dan pekerjaan ditempat kerja yang mengacu pada persyaratan kerja yang ditetapkan. Berdasarkan latar belakang tersebut, maka masalah diartikel ini dirumuskan:

1. Apakah pengalaman kerja berpengaruh terhadap kinerja pegawai PD. BPR BKK Demak Kantor Pusat Operasional, Kantor Cabang Wonosalam Dan Kantor Cabang Karang Tengah?

2. Apakah komitmen organisasi berpengaruh terhadap kinerja pegawai PD. BPR BKK Demak Kantor Pusat Operasional, Kantor Cabang Wonosalam Dan Kantor Cabang Karang Tengah

3. Apakah ada pengaruh Pengalaman Kerja dan Komitmen Organisasi terhadap kinerja karyawan PD, BPR BKK Demak Pusat Operasional, Kantor Cabang Wonosalam Dan Kantor Cabang Karang Tengah?

Penelitian ini bertujuan untuk menganalisis pengalaman kerja dan komitmen organisasi terhadap kinerja karyawan pada PD. BPR BKK Demak Kantor Pusat Operasional, Kantor Cabang Wonosalam Dan Kantor Cabang Karang Tengah. Kinerja yang baik merupakan tujuan yang ingin dicapai dari setiap perusahaan, dimana perusahaan yang bagus salah satu cirinya adalah ditandai dengan kinerja karyawannya yang baik pula. Kinerja yang baik ini dapat diwujudkan dengan adanya sumber 
daya manusia yang data di dalam perusahaan tersebut. Sumber daya manusia atau karyawan dituntut untuk selalu memberikan kinerja terbaik mereka untuk perusahaan. Pengalaman kerja merupakan bekal utama seorang karyawan untuk menekuni bidang pekerjaan tertentu, terutama bagi perusahaan yang mengutamakan bakat atau kemampuan tertentu dari seorang karyawan. Karyawan yang berpengalaman akan lebih mudah menyelesaikan pekerjaan apabila dibandingkan dengan karyawan yang kurang memiliki pengalaman kerja. Pengalaman kerja karyawan dapat dilihat dari berbagai indikator yaitu, masa kerja/lama kerja, tingkat pengetahuan dan keterampilan yang dimilik, penguasaan terhadap alat dan pekerjaan. Organisasi merupakan suatu sistem dan harus berkembang di dalam lingkungan yang senantiasa berubah. Setiap organisasi, manusia merupakan faktor penggerakan utama dalam mencapai tujuan yang telah ditetapkan. Tanpa adanya dukungan sumber daya manusia yang dapat bekerja dengan baik, maka perusahaan akan sulit mencapai tujuan yang telah ditetapkan. Terciptanya komitmen organisasi dan lingkungan kerja yang baik akan berguna untuk meningkatkan kinerja pegawai. Pentingnya sumber daya manusia maka setiap organisasi harus memperhatikan tingkat kemampuan yang dimiliki oleh para pegawai. Kinerja setiap pegawainya meningkat, maka perusahaan membutuhkan pengalaman kerja dan komitmen organisasi yang baik bagi para pegawainya. Berdasarkan uraian dari kerangka pemikiran di atas, pengaruh antara komitmen organisasi dan lingkungan kerja dengan kinerja pegawai dapat dijelaskan sebagai berikut

Dari kerangka pemikiran teoritis yang sudah diuraikan diatas dibuat paradigma penelitian pengaruh antara masing-masing variabel bebas yaitu pengalaman kerja dan komitmen organisasi terhadap variabel terkait yaitu kinerja karyawan.

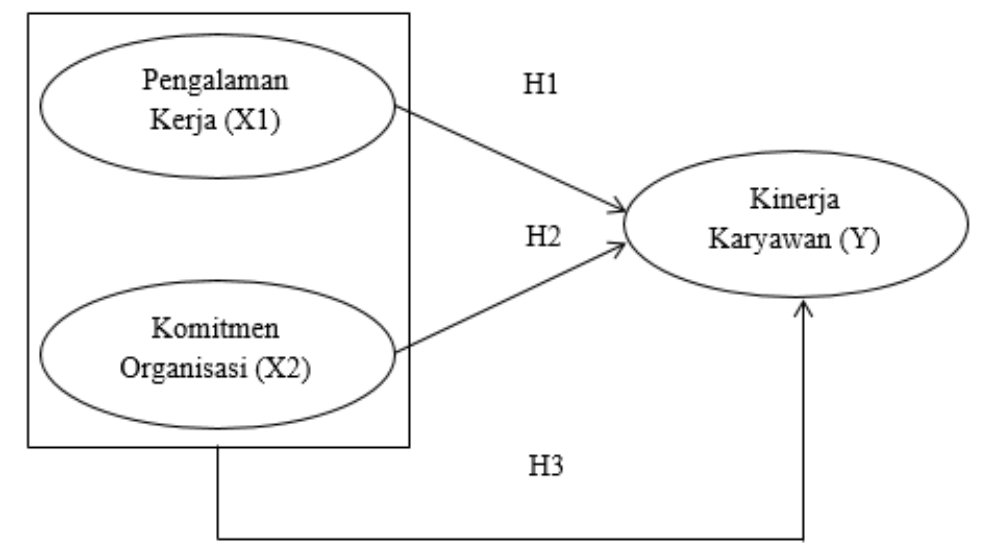

Gambar 1 Kerangka Pemikiran Teoritis

\section{Pengaruh Antar Variabel}

\section{Pengaruh Pengalaman Kerja Terhadap Kinerja Karyawan}

Pengalaman sebagai keseluruhan pelajaran yang dibentuk oleh seorang dari peristiwa-peristiwa yang dilalui dalam pelajaran hidupnya. Hasil penelitian ini pengalaman kerja diperlukan untuk meningkatkan efektif sumber daya manusia dalam perusaan, tujuannya untuk memberikan kepada perusahaan suatu kerja yang efektif dan bagi tenaga kerja sendiri sebagai sarana peningkatan produktivitas kerja. Semakin lama orang bekerja pada suatu organisasi, maka semakin mempunyai 
banyak pengalaman pula. Tetapi kecakapan akan selalu meningkat dengan meningkatnya pengelaman kerja.

Menurut penelitian yang telah dilakukan oleh Wanceslaus Billi, Erwin Resmawan dan Daud Kondorora (2018) dengan judul "Pengaruh Pengalaman Kerja Terhadap Kinerja Pegawai Di Kantor Kecamatan Laham Kabupaten Mahkamah Ulu". Hasil penelitian menunjukan bahwa pengalaman kerja berpengaruh signifikan terhadap kinerja pegawai di Kantor Kecamatan Laham kabupaten Mahkamah Ulu. Hasil penjabaran diatas menunjukan bahwa ada keterkaitan antara pengalaman kerja terhadap kinerja Karyawan. Sehingga hipotesis pertama dalam penelitian ini adalah:

$\mathrm{H}_{1}$ : Ada pengaruh positif dan signifikan pengalaman kerja terhadap kinerja karyawan

\section{Pengaruh Komitmen Organisasi Terhadap Kinerja Karyawan Terhadap Kinerja Karyawan}

Kinerja adalah apa yang dapat dikerjakan sesuai dengan tugas dan fungsinya. Sedangkan komitmen adalah perjanjian (keterikatan) untuk melakukan sesuatu dengan penuh rasa tanggung jawab. Komitmen dapat terwujud apabila individu dalam organisasi, menjalankan hak dan kewajiban mereka sesuai dengan tugas dan fungsinya masing-masing dalam organisasi. Komitmen terhadap organisasi merupakan salah satu sikap kerja. Karena ia merefleksikan perasaan seseorang (suka atau tidak suka) terhadap organisisasi ditempat kerja. Bila menyukai organisasi tersebut pasti akan berupaya untuk tetap bekerja disana. Seorang professional yang secara komitmen dapat berkomitmen bekerja secara professional serta berkomitmen organisasional dan dari upayanya tersebut mendapatkan penghargaan yang sesuai dengan kinerja yang telah diberikan dalam perusahaan.

Menurut penelitian terdahulu yang dilakukan Nunung Nurhayati (2018) dengan judul "Pengaruh Komitmen Orgaanisasi Terhadap Kinerja Karyawan pada PT. Tabungan dan Asuransi Pegawai Negeri/ Taspen (Persero) Kantor Cabang Utama Bandung”. hasil pnelitian ini menyatakan bahwa komitmen organisasi berpengaruh positif dan signifikan terhadap kinerja karyawan PT. Tabungan dan Asuransi Pegawai Negeri/ Taspen (Persero) Kantor Cabang Utama Bandung. Dari penjabaran diatas membuktikan bahwa ada pengaruh antara komitmen organisasi terhadap kinerja karyawan, sehingga hipotesis penelitian yang kedua dari penelitian ini adalah sebagai berikut:

$\mathrm{H}_{2}$ : Ada pengaruh positif da signifikan komitmen organisasi terhadap kinerja karyawan.

\section{Pengaruh Pengalaman Kerja dan Komitmen Organisasi Terhadap Kinerja Karyawan}

Kinerja karyawan PD. BPR BKK Demak akan lebih terorganisir baik dengan adanya pengalaman dan komitmen. Dengan banyaknya pengalaman terdapat kemungkinan besar untuk mewujudkan kinerja yang baik dan pengalaman akan membuat kualitas karyawan menjadi semakin baik. Hal tersebut dikarenakan karyawan mendapatkan dorongan untuk berkembang dan sudah mendapatkan pengalaman pekerjaan yang memadai, sehingga apabila pengalaman kerja dan komitmen organisasi tinggi maka kinerja karyawan akan semakin tinggi. Karyawan yang berkomitmen akan bekerja secara maksimal karena mereka menginginkan kesuksesan dalam organisasi tempat dimana bekerja. seseorang yang berkomitmen akan memiliki pemahaman tentang tugasnya, karyawan tersebut 
juga akan terbibat dalam pekerjaan yang penuh tanggung jawab, tapi pekerjaan tersebut tidak sebagai beban semata melainkan tugas dalam pelayanan publik. Komitmen karyawan tidak akan tumbuh dengan sendirinya begitu pula dengan pengalaman kerja yang juga melalui proses lamanya masa bekerja, ada hubungan yang signifikan antara pengalaman dan komitmen terhadap kinerja karyawan.

Dari penjabaran diatas dapat kita lihat bahwa pengalaman kerja dan komitmen organisasi memiliki hubungan dengan kinerja karyawan, penelitian yang sama juga pernah dilakukan oleh Nismawati (2016) dengan judul penelitian "Pengaruh Kompensasi, Pengalaman Kerja Dan Komitmen Organisasi Terhadap Kinerja Pegawai Negeri Sipil (PNS) Pada Dinas pekerjaan Umum Daerah Kabupaten Morowali". Hasil penelitian terebut menyatakan bahwa pengalaman kerja dan komitmen organisasi berpengaruh positif dan signifikan terhadap kinerja karyawan Negeri Sipil (PNS) Pada Dinas pekerjaan Umum Daerah Kabupaten Morowali. Dari beberapa uraian diatas dapat diambil kesimpulan bahwa pengalaman kerja dan komitmen organisasi memiliki pengaruh terhadap kinerja karyawan. Sehingga pada hipotesis ketiga penelitian ini adalah:

$\mathrm{H}_{3}$ : Ada pengaruh positif dan signifikan pengalaman kerja dan komitmen organissi terhadap kinerja karyawan

\section{METODE RISET}

Metode penentuan banyaknya sampel dilakukan dengan menggunakan sampling jenuh. Sampling jenuh adalah teknik penentuan sampel bila semua anggota populasi digunakan sebagai sampel. Jumlah sampel yang diambil dari PD. BPR BKK Demak Kantor Pusat Operasional, Kantor Cabang Wonosalam, dan Kantor Cabang Karang Tengah sebanyak 37 responden. metode analisis data yang digunakan adalah uji validitas, uji reliabilitas, uji asumsi klasik, (uji normalitas, uji multikolinearitas, uji heteroskedasitas), analisis regresi linier berganda, uji t (parsial), uji f (simultan), koefisien determinasi, metode Ananlisis Data penelitian ini digunakan analisis regresi linier berganda, karena penelitian ini dilakukan untuk mengetahui pengaruh Pengalaman Kerja (X1) dan Komitmen Organisasi (X2) terhadap Kinerja Karyawan (Y). Persamaan regresi linier ganda dalam penelitian ini menggunakan rumus sebagai berikut :

$$
Y=a+\beta \_1 X \_1+\beta \_2 X \_2+\varepsilon
$$

Keterangan:

Y : Variabel kinerja karyawan

A : Bilangan konstan atau nilai tetap

X_1 : Variabel pengalaman kerja

X_2 : Variabel lingkungan Kerja $\beta \_1$ : Pengaruh $X \_(1)$ terhadap y jika $X \_2$ kostan

$\beta \_2$ : Pengaruh $X \_2$ terhadap y jika $X \_1$ kostan

$\varepsilon \quad:$ Standar Error

Pengujian hipotesis ini sebagai cara untuk menentukan apakah suatu dugaan hipotesis tersebut sebaiknya diterima atau ditolak. Dalam uji hipotesis terdapat uji $\mathrm{T}$, dimana maksudnya untuk menguji pengaruh secara persial dari variabel bebas terhadap variabel terikat digunakan uji T. Sedangkan untuk menguji pengaruh secara bersama-sama digunakan uji F, secara simultan untuk menguji variabel yang 
Chikmiyyah, D., Chadiq, U. \& Yusroni, N. (2021). Analisis Pengaruh Komitmen Organisasi .....

berpengaruh antara variabel bebas (variabel X1 dan X2) terhadap variabel terikat (variabel Y). Dalam penelitian ini uji F digunakan untuk mengetahui apakah Pengalaman Kerja (X1) dan Komitmen Organisasi (X2) memiliki pengaruh secara bersama-sama terhadap Kinerja karyawan (X3).

\section{HASIL PENELITIAN DAN PEMBAHASAN}

Analisa regresi liner yang baik adalah yang memenuhi persyaratan asumsi klasik, antara lain semua data berdistribusi normal, model harus bebas dari gejala multikolinearitas dan heteroskedastisitas. Dari analisis sebelumnya telah terbukti bahwa model persamaan yang diajukan dalam penelitian ini telah memenuhi persyaratan asumsi klasik sehingga model persamaan dalam penelitian ini di anggap baik. Analisis regresi digunakan untuk mendefinisikan hubungan antara dua variabel, yaitu hubungan keterkaitan antara satu variabel atau beberapa variabel yang nilainya sudah diketahui dengan satu variabel yang nilainya belum diketahui, sifat hubungan antar variabel dalam persamaan merupakan hubungan sebab akibat (Causal Relationship). Adapun hasil uji regresi pada penelitian dapat di lihat pada tabel sebagai berikut :

Tabel 2.

Hasil Uji Regresi Linier Berganda

\begin{tabular}{lccccc}
\hline & \multicolumn{3}{c}{ Coefficients $^{\mathbf{a}}$} & & \\
\hline \multirow{2}{*}{ Model } & \multicolumn{2}{c}{$\begin{array}{c}\text { Unstandardized } \\
\text { Coefficients }\end{array}$} & $\begin{array}{c}\text { Standardized } \\
\text { Coefficients }\end{array}$ & \multirow{2}{*}{ T } & Sig. \\
\cline { 2 - 4 } & $\mathrm{B}$ & Std. Error & Beta & & \\
\hline (Constant) & 38,128 & 12,442 & & 3,064 &, 004 \\
Pengalaman Kerja (X1) &, 146 &, 213 &, 110 &, 686 &, 498 \\
Komitmen Organisasi (X2) &, 512 &, 222 &, 370 & 2,309 &, 027 \\
\hline
\end{tabular}

Sumber: Data primer yang diolah, 2019

Berdasarkan tabel diatas maka persamaannya adalah sebagai berikut :

$$
\mathrm{Y}=38,128+0,146 \mathrm{X} 1+0,512 \times 2+e
$$

Keterangan:

Y : Variabel kinerja karyawan

a : Bilangan konstan atau nilai tetap

$X_{1}$ : Variabel pengalaman kerja

$X_{2}$ : Variabel komitmen organisasi

Dari persamaan tersebut dapat dijelaskan variabel pengakaman kerja dan komitmen organisasi mempunyai arah koefisien yang bertanda positif terhadap kinerja karyawan. pengalaman kerja memberikan nilai sebesar 0,146 yang berarti bahwa pengalaman kerja mempunyai pengaruh positif. Dengan asumsi variabel lain tetap maka kinerja akan mengalami peningkatan atau konstan, komitmen organisasi kepemimpinan memberikan nilai 0,512 yang berarti bahwa komitmen organisasi mempunyai pengaruh positif. Dengan asumsi variabel lain tetap maka kinerja mengalami peningkatan atau konstan. 


\section{Uji Hipotesis}

Uji parsial atau T digunakan untuk menunjukan seberapa jauh pengaruh satu variabel penjelas atau independen secara individual dalam menerangkan variasi variabel dependen. Pengujian dilakukan denga melihat taraf signifikasi ( $p$-value), jika taraf signifikan yang dihasilkan dari perhitungan $<0,05$ atau $\mathrm{t}$ hitung $>\mathrm{t}$ tabel maka hipotesis diterima, sebaliknya jika taraf signifikasi hasil hitung $>0,05$ atau $\mathrm{t}$ hitung $<\mathrm{t}$ tabel maka hipotesis ditolak, yang dimana pada penelitian ini memiliki $\mathrm{t}$ hitung $(2,032)$. Adapun hasil uji parsial pada penelitian ini dapat dilihat pada tabel 2 sebagai berikut, Pengujian hipotesis Pertama (H1) bahwa t hitung dari variabel pengalaman kerja sebesar 0,686 < 2,032 dengan tingkat signifikansi 0,498 > 0,05 sehingga dapat disimpulkan bahwa H1 ditolak dan Ho diterima yang berarti pengalaman kerja (X1) berpengaruh positif tapi tidak signifikan terhadap kinerja karyawan (Y),sedangkan pengujian Hipotesis kedua (H2) bahwa t hitung dari variabel komitmen organisasi sebesar 2,309 > 2,032 dengan tingkat signifikansi 0,027<0,05 sehingga dapat disimpulkan bahwa H2 diterima dan Ho ditolak yang berarti terdapat pengaruh positif dan signifikan terhadap komitmen organisasi (X2) terhadap kinerja karyawan (Y).

Uji F digunakan untuk mengetahui tingkat signifikansi pengaruh variabel-variabel independen (komitmen karyawan, gaya kepemimpinan dan kompensasi) secara bersama-sama (simultan) terhadap variabel dependen (kinerja karyawan). Pengujian dilakukan dengan melihat taraf signifikasi, jika taraf signifikan yang dihasilkan dari perhitungan $<0,05$ atau $\mathrm{f}$ hitung $>\mathrm{f}$ tabel maka hipotesis diterima, sebaliknya jika taraf signifikasi hasil hitung $>0,05$ atau $\mathrm{f}$ hitung $<\mathrm{f}$ tabel maka hipotesis ditolak, yang dimana pada penelitian ini memiliki f hitung $(3,25)$. Adapun uji simultan pada penelitian uji ANOVA (uji F) dapat dilihat bahwa nilai f hitung sebesar 3,756 > 3,25 dengan tingkat signifikansi 0,048< 0,05. Hal ini menunjukkan bahwa secara simultan atau bersama-sama pengalaman kerja dan komitmen organisasi berpengaruh dan signifikan terhadap kinerja karyawan. Untuk besarnya $R$ Square adalah 0,140. Hal ini berarti variabel-variabel bebas yaitu variabel pengalaman kerja dan variabel komitmen organisasi dapat menjelaskan variasi dari variabel terkait kinerja karyawan sebesar 14\% sedangkan sisanya $86 \%$ dipengaruhi atau dijelaskan oleh variabel-variabel lain yang tidak dimasukkan dalam model penelitian. Adapun standart error of estimate (SEE) adalah 3,708. Makin kecil SEE akan membuat model regresi semakin tepat memprediksi variabel terkait.

Berdasarkan hasil pengujian secara statistik dapat terlihat bahwa secara persial tidak semua variabel bebas berpengaruh secara signifikan terhadap variabel terkait. Penmbahasan hasil penelitian hasil analisis pengaruh pengalaman kerja dan komitmen organisasi terhadap kinerja karyawan PD. BPR BKK Demak Kantor Pusat Operasional, Kantor Cabang Wonosalam dan Kantor Cabang Karang Tengah dari masing-masing pengaruh variabel dijelaskan sebagai berikut:

\section{Pengaruh Pengalaman Kerja terhadap Kinerja Karyawan}

Hasil dari pengujian menunjukkan bahwa t hitung 0,686 < 2,032 dengan tingkat signifikansi 0,498 > 0,05 sehingga dapat disimpulkan bahwa hipotesis dalam penelitian ini menolak H1 dan 
menerima Ho yang berarti pengalaman kerja tidak berpengaruh signifikan terhadap kinerja karyawan PD. BPR BKK Demak Kantor Pusat Operasional, Kantor Cabang Wonosalam dan Kantor Cabang karang Tengah. Artinnya semakin meningkatnya pengalaman kerja tidak dapat meningkatkan kinerja karyawan. Hal ini menunjukkan bahwa pengalaman kerja yang diperoleh karyawan selama ini tidak mempengaruhi kinerja mereka, mungkin dari jenis tugas yang diberikan oleh perusahaan berbeda atau tidak sama dengan pengalaman yang dimiliki karyawan dalam memahami tugas sebelumnya.

Berdasarkan hasil penelitian pada variabel pengalaman kerja indikator yang memiliki indeks nilai tertinggi yaitu pada indikator tingkat pengetahuan dan keterampilan yang telah dimiliki, yang berarti bahwa tingkat kemampuan karyawan dalam melaksanakan tugas-tugas pekerjaan, mampu menguasai pekerjaan yang diberikan dan memiliki keterampilan yang menghasilkan kualitas kerja yang optimal. Untuk indikator dengan nilai indeks terendah adalah lama waktu/masa kerja, hal tersebut mungkin disebabkan karyawan yang memiliki pengalaman belum tentu dapat menyelesaikan tugastugas secara efektif dan efesien atau belum sepenuhnya memahami prosedur kerja yang berlaku di perusahaan. Hasil penelitian ini sejalan dengan penelitian yang dilakukan oleh Muthia Amanta Dwi Putri (2017) yang menyatakan bahwa pengalaman kerja tidak berpengaruh signifikan terhahap kinerja karyawan di PT. Jasa Raharja Putera Cabang Pekanbaru.

Indikator-indikator yang dijadikan tolak ukur pengujian pengalaman kerja menurut Foster (2001), yaitu: pertama lama waktu/masa kerja, ukuran tentang lama waktu atau masa kerja yang telah ditempuh seseorang dapt memahami tugas-tugas suatu pekerjaan dan telah melaksanakan dengan baik. Kedua tingkat pengetahuan dan keterampilan yang telah dimiliki, pengetahuan merujuk pada konsep, prinsip, prosedur, kebijakan, atau informasi lain yang dibutuhkan oleh karyawan, pengetahuan juga mencakup kemampuan untuk memahami dan menerapkan informasi pada tanggung jawab pekerjaan, sedangkan keterampilan merujuk pada kemampuan fisik yang dibutuhkan untuk mencapai atau menjalankan suatu tugas atau pekerjaan. Ketiga penguasaan terhadap pekerjaan dan peralatan, tingkat penguasaan sesorang dalam pelaksanaan aspek-aspek teknik peralatan dan teknik pekerjaan.

\section{Pengaruh Komitmen Organisasi terhadap Kinerja Karyawan}

Hasil pengujian menggunakan bantuan Softwere SPSS dapat diketahui dari tabel Coefficients bahwa nilai koefisien pengaruh komitmen organisasi berpengaruh positif dan signifikan terhadap kinerja karyawan PD. BPR BKK Demak Kantor Pusat Operasional, Kantor Cabang Wonosalam dan Kantor Cabang Karang Tengah. Sedangkan untuk uji persial menunjukan bahwa nilai t hitung dari pengaruh variabel komitmen organisasi terhadap kinerja karyawan adalah 2,309 > t tabel 2,032 dengan tingkat signifikansi $0,027<0,05$. Pengujian ini secara statistik membuktikan bahawa komitmen organisasi berpengaruh poitif dan signifikan terhadap kinerja karyawan PD. BPR BKK Demak Kantor Pusat Operasional, Kantor Cabang Wonosalam dan Kantor Cabang Karang Tengah.

Berdasarkan hasil penelitian pada variabel komitmen organisasi indikator yang memiliki indeks nilai tertinggi yaitu pada indikator komitmen afektif, sehingga dapat diartikan bahwa keterikatan 
emosional karyawan untuk mengabdi bekerja diperusahaan tidak diragukan lagi. Untuk indikator dengan nilai indeks terendah adalah komitmen kelanjutan, hal tersebut mungkin disebabkan perusahaan kurang memberi kesejahteraan dengan baik bagi karyawannya. Penelitin ini sejalan dengan penelitian yang dilakukan Arina Nurandini dan Eisha Lataruva (2014), yang menunjukan bahwa komitmen organisasi berpengaruh positif dan signifikan terhadap kinerja pegawai Perum PERUMNAS Jakarta. Indikator-indikator yang dijadikan tolak ukur pengujian komitmen organisasi menurut Mayer dan Allan dalam Kaswan (2012), yaitu: Pertama adalah komitmen afektif, menunjukkan kuatnya keinginan emosional karyawan untuk beradaptasi dengan nilai-nilai yang ada agar tujuan dan keinginannya untuk tetap diorganisasi dapat terwujud. Kedua adalah komitmen kelanjutan, merupakan komitmen yang didasari atas kekhawatiran seseorang terhadap kehilangan sesuatu yang telah diperoleh selama ini dalam organisasi, seperti: gaji, fasilitas, dan yang lainnya, hal-hal yang menyebabkan adanya komitmen kelanjutan, antara lain adalah umur, jabatan, dan berbagai fasilitas serta berbagai tunjangan yang diperoleh. Ketiga adalah komitmen normative, menunjukan tanggung jawab moral karyawan untuk tetap tinggal dalam organisasi, penyebab timbulnya komitmen ini adalah tuntutan sosial yang merupakan hasil pengalaman seseorang dalam berinteraksi dengan sesame atau munculnya kepatuhan permanen terhadap seorang panutan atau pemilik organisasi dikarenakan balas jasa, respek sosial, budaya atau agama.

\section{Pengaruh Pengalaman Kerja Dan Komitmen Organisasi terhadap Kinerja Karyawan}

Berdasarkan uji ANOVA (uji F) hasil peneilitian dapat dilihat bahwa nilai $\mathrm{f}$ hitung sebesar 3,756 3,25 dengan probabilitas signifikansi 0,048 > 0,05. Hal ini berarti bahwa H3 diterima dan Ho ditolak. Pengujian ini secara statistik membuktikan bahwa pengalaman kerja dan komitmen organisai secara bersama-sama berpengaruh simultan dan signifikan terhadap kinerja karyawan pada PD. BPR BKK Demak Kantor Pusat Operasional, Kantor Cabang Wonosalam dan Kantor Cabang Karang Tengah, hasil penelitian pada variabel kinerja karyawan indikator yang memiliki indeks nilai tertinggi yaitu pada indikator kemandirian, sehingga dapat diartikan bahwa karyawan bersedia melakukan pekerjaan dan bersedia memperbaiki kesalahan tanpa harus diperintah atau diminta dahulu oleh atasan. Untuk indikator dengan nilai indeks terendah adalah kuantitas, hal tersebut munkin disebabkan karyawan dalam bekerja belum mampu menyelesaikan tugas dengan target yang ditetapkan perusahaan. Penelitin ini sejalan dengan penelitian yang dilakukan Nismawati (2016) yang menunjukkan bahwa pengalaman kerja dan komitmen organisasi berpengaruh positif dan signifikan terhadap kinerja PNS pada dinas pekerja umum daerah kabupaten morowali.

Indikator-indikator yang dijadikan tolak ukur pengujian kinerja karyawan adalah menurut Robbins dalam Bintoro (2017), yaitu: Pertama adalah kualitas, kualitas kerja diukur dari persepsi karyawan terhadap kualitas pekerjaan yang dihasilkan serta kemampuan tugas terhadap keterampilan dan kemampuan karyawan. Kedua adalah kuantitas, merupakan jumlah yang dihasilkan dinyatkan dalam istilah seperti jumlah unit, jumlah siklus aktivitas yang diselesaikan. Ketiga adalah ketepatan 
waktu, merupakan tingkat aktivitas yang diselesaikan pada awal waktu yang dinyatakan, dilihat dari sudut koordinasi dengan hasil output serta memaksimalkan waktu yang tersedia untuk aktivitas lain. Keempat adalah efektivitas, merupakan tingkat penggunaan sumber daya organisasi (tenaga, uang, teknologi, bahan baku) dimaksimalkan dengan maksud menaikkan hasil dari setiap unit dalam penggunaan sumber daya. Kelima adalah kemandirian, merupakan tingkat seorang karyawan yang nantinya akan dapat menjalankan fungsi kerjanya.

\section{KESIMPULAN DAN SARAN}

Berdasarkan hasil analisis data yang telah dijelaskan, maka dapat diambil kesimpulan sebagai berikut:

1. Pengalaman kerja yang dimiliki oleh karyawan PD BPR BKK Demak Kantor Pusat Operasional, Kantor Cabang Wonosalam dan Kantor Cabang Karang Tengah, kiranya dapat terus meningkatkan kinerjanya lewat pengalaman bekerjanya, terutama tingkat pengetahuan dan keterampilan yang dimiliki karyawan, karena mengingat hasil penelitian yang menunjukan bahwa indikator tingkat penegetahuan dan keterampilan yang memiliki indeks nilai tertinggi dalam variabel pengalaman kerja yaitu 168,35\%. Apabila seorang karyawan semakin menguasai pekerjaan yang telah berikan maka akan menghasilkan kualitas kerja yang optimal.

2. Perusahaan harus mempertahankan komitmen organisasinya, terutama komitmen afektif yang telah dimiliki karyawan maupun atasan yang sudah merasa terlibat dan memberikan dampak banyak terhadap perusahaan akan senantiasa menciptakan hubungan kerja yang baik antar sesama karyawan maupun atasan, dengan begitu dapat terciptanya kenyamanan dalam lingkungan kerja sehingga komitmen karyawan terhadap perusahaan dapat meningkat. Mengingat komitmen afektif dalam variabel komitmen organisasi ini yang memiliki nilai indeks paling rtinggi yaitu $183,15 \%$.

3. Kinerja karyawan dalam perusahaan harus tetap dipertahankan terutama kemandirian yang dimiliki oleh karyawan untuk kemajuan perusahaan sangat baik bahkan jika bisa harus ditingkatkan. Sebab indikator kemandiriran dalam variabel kinerja karyawan dalam penelitian ini yang memiliki nilai indeks tertinggi yaitu sebesar $175.75 \%$. 


\section{DAFTAR PUSTAKA}

Amwiarni, Sartika. (2015). Pengaruh Pengalaaman Kerja, Disiplin Kerja dan Pengalaman Kerja Terhadap Kinerja Pegawai Dinas Pendapatan, Pengelolaan Keuangan dan Aset Daerah. Vol. 3 No. 1 Hal. 55

Riyadi, Bagus Aries. (2015). Pengaruh Pengalaman Kerja Terhadap Kinerja Karyawan Pada Toko Emas Semar Nganjuk. Equilibrium: Jurnal Ilmiah Ekonomi \& Pembelajarannya, Vol. 3, No. 1

Bintoro, (2017). Manajemen Penilaian Kinerja Karyawan. Penerbit GAVA MEDIA: Ypgyakarta

Edy Sutrisno, (2010). Budaya Organisasi, Penerbit PRENADAMEDIA: Jakarta.

Septiani, Elisa. (2018). Pengaruh Komitmen Organisasi Dan Lingkungan Kerja Terhadap Kinerja Pegawai Pada Dua Puskesmas Di Kabupaten Bandung Selatan. Skripsi(S1) thesis, Perpustakaan Fakultas Ekonomi dan Bisnis Unpas Bandung. hal 27

Resmawan, Erwin., Billi, Wanceslaus., dan Kondorura, Daud. (2018). Pengaruh Pengalaman Kerja Terhadap Kinerja Pegawai di Kantor Kecamatan Laham Kabupaten Mahkamah Ulu. E-Journal Pemerintahan Integratif, Vol. 6, No. 3, Hal. 467

Ghozali, Imam. (2013). Aplikasi Analisis Multivariate dengan Program IBM SPSS21. Semarang: Badan Penerbit Universitas Diponegoro

Greenberg dan Baron, (2000). Behavior in organizations: Understan-ding and managing the human side of work (7th ed.). NJ: Prentice Hall.

Widiana, Muslichah Erma. (2015). Variabel Dan Indikator Yang Mempengaruhi Komitmen Dan Kinerja Organisasi Pemerintah, UNBARA Manajemen Press, Univ. Bhayangkara Surabaya.

Putri, Muthia Amanta Dwi. (2017). Pengaruh Pengalaman Kerja, Penilaian Prestasi Kerja Dan Hubungan Kerja Terhadap Kinerja Karyawan Di PT. Jasaraharja Putera Cabang Pekanbaru. Jurnal online mahasiswa Fakultas Ekonomi Universitas Riau, Vol. 4 No. 1

Nismawati. (2016) Pengaruh Kompensasi, Pengalaman Kerja dan Komitmen Organisasi Terhadap Kinerja Pegawai Sipil (PNS) pada Dinas Pekerjaan Umum Daerah Kabupaten Morowali. EJournal Katalogis, Vol. 4 No. 8

Monats, Rohida Utami (2016). Pengaruh Tingkat Pendidikan, Pengalaman Kerja dan Komitmen Organisasi Terhadap Kinerja Pengelola Keuangan Pada Satuan Kerja Perangkat Daerah Kabupaten Indragili Hilir. Jurnal online mahasiswa FE Univ Riau Vol. 3 No. ! Hal. 753.

Salma D. (2016). Pengaruh Komitmen Organisasi, Motivasi Kerja Dan Pengalaman Kerja Terhadap Kinerja Pegawai Honor Lepas Pada Puskesms Dikabupaten Morowali. Jurnal Katalogis. Vol. 4 No. 8

Sugiyono. (2016). Metode Penelitian Manajemen. Badan Penerbit Alfabeta: Bandung 